\title{
Article
}

Mycosphere

\section{Triadelphia moubasherii sp. nov., from the gut of red palm weevils, Rhynchophorus ferrugineus Olivier}

\author{
Abdel-Sater MA ${ }^{1,2, *}$ and Zeinab Soliman ${ }^{2}$ \\ ${ }^{1}$ Assiut University, Faculty of Science, Department of Botany and Microbiology, P.O. Box 71516, Assiut, Egypt. \\ ${ }^{2}$ Assiut University, Assiut Universiy Mycological Centre, P.O. Box 71516, Assiut, Egypt.
}

Abdel-Sater MA and Zeinab Soliman 2017 - Triadelphia moubasherii sp. nov., from the gut of red palm weevils, Rhynchophorus ferrugineus Olivier. Mycosphere 8(8), 1128-1237, Doi 10.5943/mycosphere/8/8/18

\begin{abstract}
During surveys of the mycota inhabiting guts of some insect species in Assiut area, Egypt, an interesting isolate of a dematiaceous hyphomycete was obtained from a gut sample (out of 11 investigated) of the red palm weevil, Rhynchophorus ferrugineus. This isolate was morphologically and genotypically identified as a new species in the genus Triadelphia (Triadelphia moubasherii Abdel-Sater and Zeinab Soliman, with $94 \%$ ITS similarity with T. disseminata Madrid \& J. Edathodu, GenBank accession no. KC489510). The type strain of the new species was deposited at Assiut University Mycological Centre Culture Collection and given AUMC number 10746 and the ITS gene sequence was deposited at the National Center for Biotechnological Information (NCBI) and accession numbers is given as KY611849. Description and photos of the new species are presented.
\end{abstract}

Key words - Assiut - insect - pleomorphic - Triadelphia disseminata - T. pulvinata

\section{Introduction}

During search of filamentous and yeast fungi in the guts of two insect species, namely honey bees (Apis mellifera L., order: Hymenoptera, family: Apidae), black beetles (Pterostichus melanarius Illiger, order: Coleoptera, family: Carabidae), and to our knowledge, for the first time worldwide from the gut of adult red palm weevils, RPW (Rhynchophorus ferrugineus, order: Coleoptera, family: Curculionidae), yeasts and filamentous fungi were isolated more frequently from the latter (Moubasher et al. 2017). An interesting filamentous strain was recovered from a gut sample of red palm weevil that could be designated based on macroscopic and microscopic features to the genus Triadelphia.

The pleomorphic genus Triadelphia Shearer \& Crane was erected by Shearer \& Crane (1971) to accommodate a sporodochial hyphomycete, T. heterospora Shear \& Crane, isolated from wood blocks submerged in the Patuxent River, Maryland, USA and characterized by two different forms of conidia. The gregarious to caespitose, globose to subglobose to ampulliform conidiogenous cells borne directly on vegetative hyphae are the hallmark of Triadelphia. A similar fungus, Dicoccum inquinanis Sacch., found on decaying wood, was transferred into Triadelphia by Hughes \& Pyrozynski in (1972) as Triadelphia inquinans (Sacc.) S. Hughes \& Pyroz.. Maggi et al. (1978) described two additional species from the rhizosphere soil of Loudetia simplex in the Ivory Coast, 
Triadelphia loudetia Maggi, Bartoli \& Rambelli, and T. pulvinata Maggi, Bartoli \& Rambelli, but mentioned only one form of conidia. In 1982, Consantinescu \& Samson described a fifth species, $T$. romanica O. Const. \& Samson from hen egg shell and proposed a new combination (Triadelphia alabamensis (Matsushima) O. Const. \& Samson) for Stemphyliomma alabamense Matsushima. Reexamination of Triadelphia heterospora and T. inquinanis dried herbarium specimens, as well as living cultures of T. loudetia and T. pulvinata showed that these species also possess 3-5 forms of conidia, and the generic description of the genus is emended accordingly and a key for the six species was provided (Constantinescu \& Samson 1982).

Later, a new combination, Triadelphia uniseptata (Berk. \& Br.) P.M. Kirk (1983) was proposed for Sporidesmium uniseptatum Berk. \& Br. In addition, six species of Triadelphia have been described: Triadelphia stilboidea Mercado \& Oastaneda (1983) from Cuba, T. hungarica Révay (1987) on forest litter from Hungary, T. australiensis B. C. Sutton (1989) from Queensland, Australia, T. diversa Tzean \& Chen (1989) on fallen, decayed angiosperm tree stem from Taiwan, and T. queenslandica Matsushima (1989); and T. morgoensis Revay (1992) on decaying wood from Hungary and a key for 12 species was proposed (Revay 1992). Also, T. stilboidea (which is characterized by peculiar synnematous conidiophores, tretic conidiogenous cells and two kinds of conidia) is probably not closely related to T. heterospora, the type species of Triadelphia, or to other species presently referred to this genus (Revay 1992).

In 1996, T. centroseptata was described on dead rachis of Cocos nucifera by Venkateshwarlu et al. (1996), however it was not validly published (MycoBank, Index Fungorum, also refer to Patil \& Borse 2015).

Triadelphia pulvinata was originally described from the rhizosphere of the grass Loudetia simplex in the Ivory Coast as having only one asexual morph (Maggi et al. 1978), but three morphs were reported later by Constantinescu \& Samson (1982) and Tzean \& Chen (1989). The second isolation of Triadelphia pulvinata was also from soil contaminated with bat guano in Saudi Arabia and its pathogenicity to experimentally infected mice has been proven (Al-Hedaithy \& Leathers 1987). The third record of this species was from a case of eyelid infection of an apparently immunocompetent patient, represents the first human infection caused by $T$. pulvinata (AlHedaithy 2001) and subsequently the fourth isolation from a fatal disseminated infection in a female with leukaemia in Riyadh Province, Saudi Arabia (Edathodu et al. 2013).

In June 2015, the isolate of Triadelphia pulvinata that was recovered from the fatal disseminated infection in the immunocompromised human patient in Riyadh Province, Saudi Arabia was reidentified and described as a new species based on ITS gene sequencing as $T$. disseminata Madrid \& J. Edathouda (Madrid et al. 2015). Of these 15 species known taxa, only $T$. uniseptata, Kirk 1983, T. australiensis, Sutton 1989, and T. centroseptata, Venkateshwarlu et al. 1996 show one conidial form, but all other species show at least two (up to five) conidial forms (synasexual morphs) on natural substrates and in culture (Constantinescu \& Samson 1982, Tzean \& Chen 1989, Révay 1992). Also, no sexual forms have been linked to all Triadelphia species except T. uniseptata was reported as the asexual morph of Ascolacicola aquatica, a member of Sordariales (Ranghoo \& Hyde 1998, Ranghoo et al. 1999, Maharachchimbura et al. 2016). Under unitary nomenclature, T. uniseptata might need to be considered a synonym of Ascolacicola aquatica (Madrid et al. 2015). However, in the analysis of Réblová et al. (2016), T. uniseptata nested within the monophyletic Ascotaiwania clade as a sister to A. mitriformis.

\section{Materials \& Methods}

\section{Collection and dissection of insects to obtain guts}

A total of 11 samples from red palm weevils, RPW (Rhynchophorus ferrugineus Olivier, order: Coleoptera, family: Curculionidae) were kindly supplied by the Faculty of Agriculture, Assiut University, in July 2013, February and March 2014. Insects obtained were put in clean glass bottles and kept for 3 days with slightly moistened filter paper so that surface debris is removed. Thereafter, insect samples were put each in a $250 \mathrm{ml}$ conical flask containing $95 \%$ ethyl alcohol 
for 1-2 min and washed several times with sterile distilled water for surface sterilization. They were dissected using forceps in a sterile Petri dish, and the gut was removed aseptically from body.

\section{Isolation of gut inhabiting fungi from $R P W$}

The gut is transferred and crushed into a sterile $1.5 \mathrm{ml}$ Eppendorf tube containing $200 \mu \mathrm{l}$ of $0.7 \%$ sterile saline solution. All the solution (including gut pieces) was spread over the surface of yeast extract-malt extract-peptone-glucose agar, YM and acidified yeast extract-malt extractpeptone-glucose agar, AYM (Wickerham 1951) plates (at least 3 replicate-plates for each medium type and each gut sample). The inoculated plates were incubated at $25^{\circ} \mathrm{C}$ for 7 days (Suh \& Blackwell 2004). The developing fungal colonies were checked and observed under a microscope. During precise examination, an interesting isolate of a dematiaceous hyphomycete was obtained from a gut sample. This isolate was morphologically identified as a species in the genus Triadelphia. However, it was dissimilar in some aspects, when compared, to all known Triadelphia species.

\section{Morphology}

Culture characteristics and microscopic characters were determined after incubation at $25^{\circ} \mathrm{C}$ in the dark for 14 days on potato-dextrose agar (PDA), potato-sucrose agar (PSA), potato-carrot agar (PCA), Czapek yeast extract agar (CYA), oatmeal agar (OA) and Sabouraud dextrose agar (SDA) (for media composition refer to Samson et al. 2004). Measurements were assessed from slides mounted in lactophenol cotton blue, using Carl Zeiss, Axiostar Plus microscope, Microimaging GmbH, Göttingen, Germany, magnification up to 1000×.

\section{Genotypic identification of the Triadelphia isolate}

The isolate was characterized by ribosomal DNA sequence analysis. Sequence data were obtained by growing the fungus on MEA for $4 \mathrm{~d}$ at $25^{\circ} \mathrm{C}$. DNA was extracted, isolated and the Internal transcribed spacer (ITS) sequences of nuclear ribosomal DNA were amplified in SolGent Company, Daejeon, South Korea; using the universal primers ITS 1 (5' - TCC GTA GGT GAA CCT GCG G - 3'), and ITS 4 (5'- TCC TCC GCT TAT TGA TAT GC -3') (Moubasher \& Zeinab Soliman 2011, Abdel-Sater et al. 2016). Contig was created from the sequence data using CLCBio Main Workbench program 8.5.1 and the sequence obtained was further analyzed using BLAST from the National Center of Biotechnology Information (NCBI) website. Sequences obtained together with those retrieved from the GenBank database were subjected to the Clustal W analysis using MegAlign software version 5.05 (DNASTAR Inc., Madison, Wisconsin, USA) for the phylogenetic analysis (Thompson et al. 1994). The type strain and the holotype of the newly descried species were deposited at Assiut University Mycological Centre Culture Collection and Herbarium (AUMC) respectively, and the ITS gene sequence was deposited at the National Center for Biotechnological Information (NCBI).

\section{Results}

Morphological and genotypic characters revealed that the current isolate is quite different from all known Triadelphia species. Therefore it could be designated to a new species.

\section{Description of the new species}

Triadelphia moubasherii Abdel-Sater \& Zeinab Soliman, sp nov.

Figs1-2 MycoBank: MB 820030, Facesoffungi number: FoF 03373

Etymology - the specific name refers to the distinguished professor of Mycology Professor AH Moubasher, the founder of Assiut University Mycological Centre, Assiut University, Egypt. Identification of the current strain was based on phenotypic features and fungal ribosomal DNA sequence analysis. 

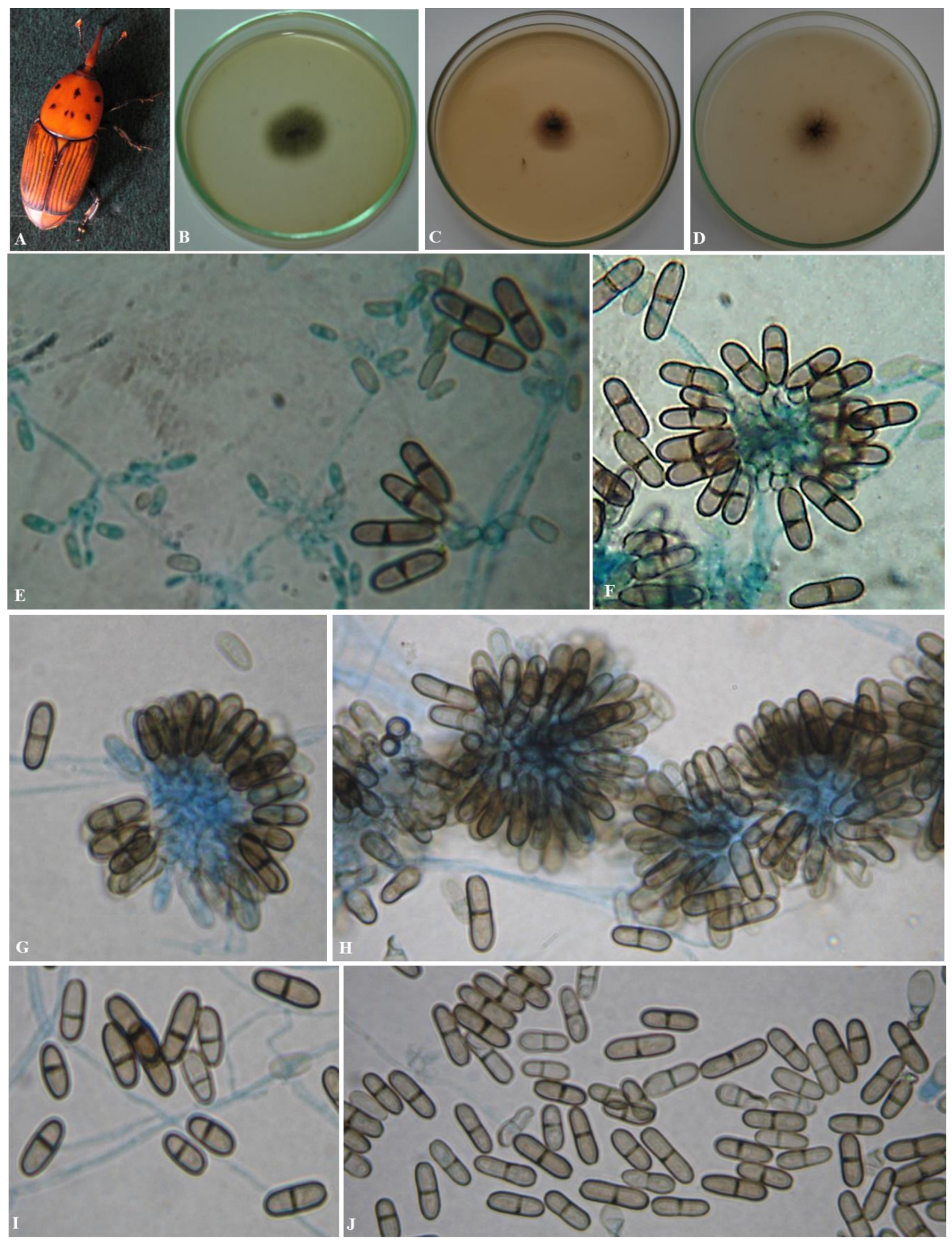

Fig 1 A: The insect Rhynchophorus ferrugineus from its gut Triadelphia moubasherii AUMC 10746 was isolated, B: on PDA, C: on SDA, D: on OA; E-J: the isolated phialides and sporodochium-like structures bearing one-septate, cylindrical, rounded at both ends, brownish conidia. 

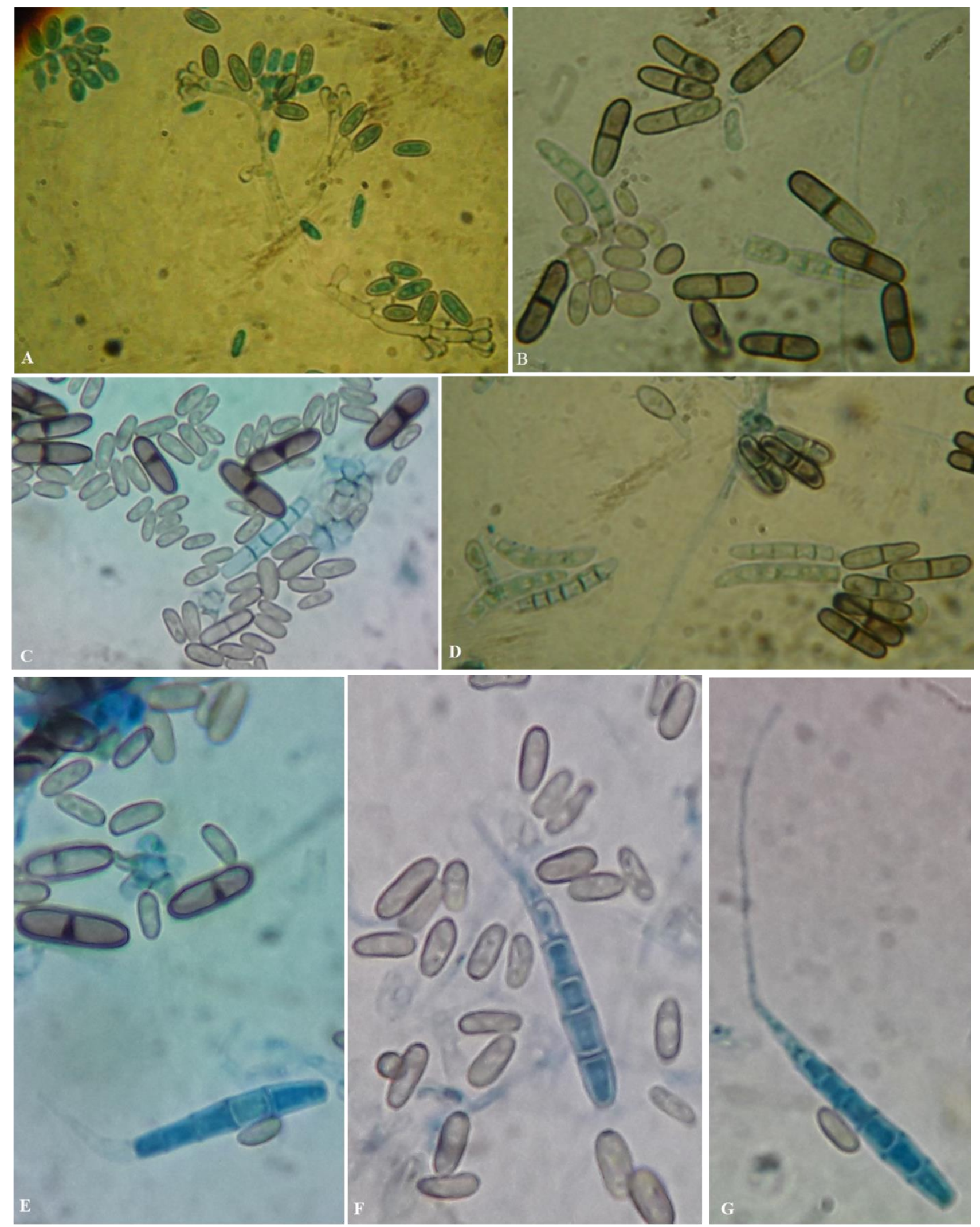

Fig 2 Triadelphia moubasherii AUMC 10746, A: phialides bearing one-celled conidia, B-D: the 3 types of conidia (one-celled, two-celled and multiseptate (up to 5-septate), E-G: one-celled and 5-7 multiseptate conidia with long beak). 
Examination of microscopic features from potato dextrose agar (PDA) tease mounts in lactophenol cotton blue revealed three distinct types of conidia: 1- cylindrical, rounded at both ends, brown, one-septate, septum thick and situated above the middle, (10-) 14-16 (-19)×3-4 $\mu \mathrm{m}$, smooth-walled, conidiogenous cells phialidic, isolated when young but soon aggregated into sporodochium-like structures, hyaline or pale brown; 2- allantoid (curved) to reniform, unicellular, rounded at both ends, hyaline to pale brown, smooth- and thin-walled, 5-9 $(-12) \times 2-3(-3.5) \mu \mathrm{m}$, conidiogenous cells solitary or aggregated, hyaline, flask-shaped; 3- multiseptate (mostly 5- but up to 7-septate), acicular to obclavate, slightly curved, 20-100 (including the beak) $\times 3-4 \mu \mathrm{m}$, but conidial body only up to (20-) 30-40 (-50) $\times 3-4 \mu \mathrm{m}$, hyaline, smooth and thin-walled, base truncate, conidia gradually tapering into a long $0.5-1 \mu \mathrm{m}$ wide, hyaline, apical peak; conidiogenous cells solitary (Figs 1, 2).

The three types of conidia are common on potato dextrose agar (PDA), potato sucrose agar (PSA), potato carrot agar (PCA) and Czapek yeast extract agar (CYA) after 14 days of incubation at $25^{\circ} \mathrm{C}$, however on oat agar (OA) and Sabouraud dextrose agar (SDA) the most common is the $2^{\text {nd }}$ conidial type, and the $3^{\text {rd }}$ is very rare. Colony surface and reverse brownish on all cultivation media.

The isolate was also characterized by ribosomal DNA sequence analysis (Table $1 \&$ Fig 3). Sequence data obtained was analyzed using BLAST from the National Center of Biotechnology Information (NCBI) website and compared to the ex-type strain of $T$. disseminata CBS 138592=UTHSCSAR-4903, ITS sequence GenBank KC489510. The ITS sequence was 94\% identical to the $T$. disseminata ex-type strain. The low percentage identity and the difference in morphology from $T$. pulvinata and $T$. disseminata indicated that it is a different and new species. Thus, the identity of this strain was confirmed to be a new species based on the ITS sequence and consistency with the previously reported morphological features described above.

Material examined - Egypt, Assiut, from the gut of red palm weevils (Rhynchophorus ferrugineus Olivier), 12 July 2013, collector and isolator Zeinab Soliman, holotype AUMC 10746, living culture of the new species as well as dried materials are deposited at the culture collection of the Assiut University Mycological Centre, Assiut, Egypt, and ITS sequence GenBank KY611849 was deposited in the National Centre of Biotechnology Information (NCBI) (http: //www.ncbi.nlm.nih.gov.).

Here, the isolation and description of T. moubasherii is registered, as the first Triadelphia species to be isolated from the gut of red palm weevils, RPW.

\section{Discussion}

In this paper Triadelphia moubasherii is introduced as a new species that is phylogenetically distinct from other Triadelphia species with DNA sequence data in GenBank. Unfortunately no DNA sequence data are available for most Triadelphia species, therefore all the known species need to be sequenced to establish a complete phylogeny of the genus. The new species is also phenotypically different from all other species in the genus. It produces three forms of conidia in culture [one-septate of cylindrical shape (a-type), multiseptate acicular to obclavate (c-type), and non-septate allantoid to reniform conidia (e-type)]. It shared this feature with other 4 Triadelphia species, its cylindrical conidia (together with $T$. pulvinata and T. disseminata) but differs in having only one septum from those of $T$. loudetiae and $T$. morgoensis whose cylindrical conidia having two septa. Also, it could be distinguished from the other two closely related species (T. pulvinata and $T$. disseminata) by their conidial sizes (Table 2). Species of Triadelphia were reported from decaying wood (Shearer \& Crane 1971, Hughes \& Pyrozynski 1972, Revay 1992), decayed angiosperm tree stem (Tzean \& Chen 1989), forest litter (Revay 1987), dead rachis of Cocos nucifera (Venkateshwarlu et al. 1996), rhizosphere soil (Maggi et al. 1978), soil contaminated with bat guano (Al-Hedaithy \& Leathers 1987), hen egg shell (Constantinescu \& Samson 1982), a case of eyelid infection of an apparently immunocompetent patient (Al-Hedaithy 2001) and from a fatal disseminated infection in a female with leukaemia (Edathodu et al. 2013, Madrid et al. 2015). From ecological point of view, the new species broaden, and for the first time, the distribution of the 
genus Triadelphia to include other habitats (guts of insects, anaerobic environments), that probably give the opportunity to these fungi to play, in part, a role in their life cycles on their hosts.

\section{Key of Triadelphia species (modified from those of Constantinescu \& Samson 1982, Revay 1992)}

1. Only one conidial form is present .3

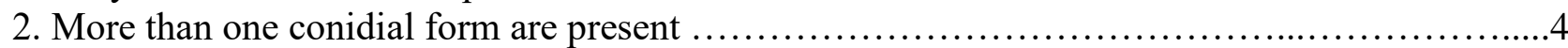

3. Conidia clavate, $8.5-10 \times$ x 4.5-6 $\mu \mathrm{m}$............................................ australiensis

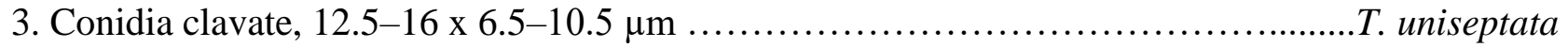

3. Conidia clavate, $12.5-21(17.5) \times$ 4.0-8.5 (5.5) $\mu \mathrm{m}$ in size ....................... centroseptata

4. At least one conidial form is broadly obclavate, fusiform ellipsoidal, with black band at the septa

4. Not as above, acicular to obclavate conidia present

5. Conidia fusiform-ellipsoidal, without acerose end cells

T. alabamensis

5. Conidia broadly obclavate or fusiform-ellipsoidal with acerose end cells ....................6

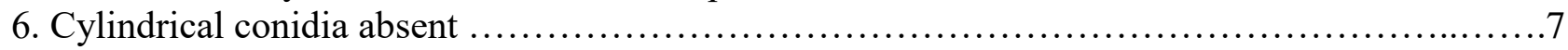

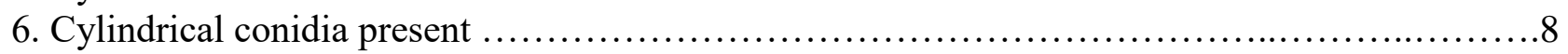

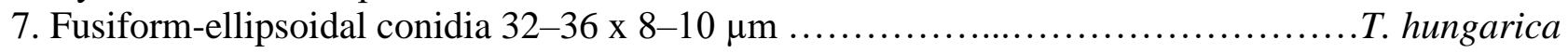

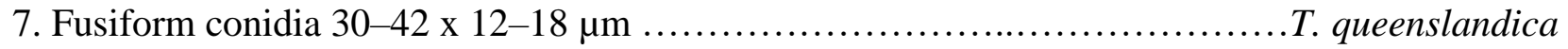

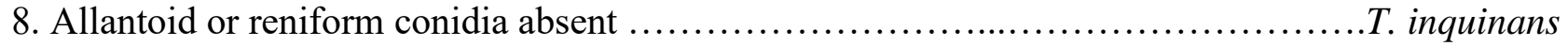

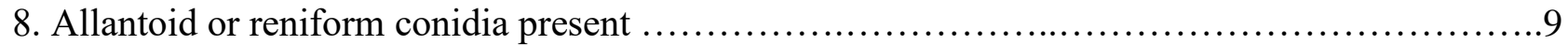

9. Clavate conidia absent ........................................................ heterospora

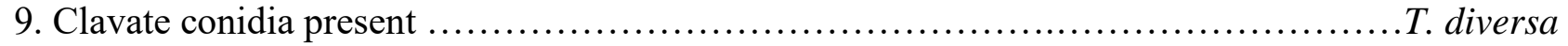

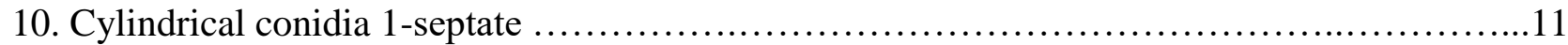

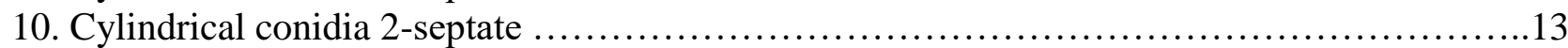

11. Clavate conidia present, cylindrical conidia $6.5-14$ x 2.5-4 $\mu \mathrm{m}$........................ romanica

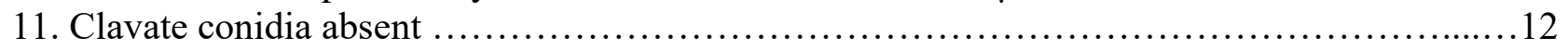

12. Cylindrical conidia 5-11 x 2.5-4 $\mu \mathrm{m}$, acicular to obclavate conidia 3-4 septate, 43-227 $\mu \mathrm{m}$ long .................................................................... disseminata 12. Cylindrical conidia 9-12 x 3-3.5 $\mu \mathrm{m}$, acicular to obclavate conidia 5-7 septate, 40-160 $\mu \mathrm{m}$

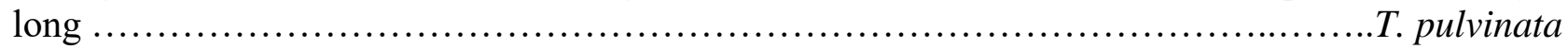

12. Cylindrical conidia 10-19 x 3-4 $\mu \mathrm{m}$, acicular to obclavate conidia up to 4-7 septate, $20-100 \mu \mathrm{m}$ long

T. moubasherii

13. Cylindrical conidia brownish, 9-19 x 3-5 $\mu \mathrm{m}$

.T. loudetiae

13. Cells of the cylindrical conidia differently pigmented, 16-25.6 x 3.2-4.8 $\mu \mathrm{m}$......T. morgóensis

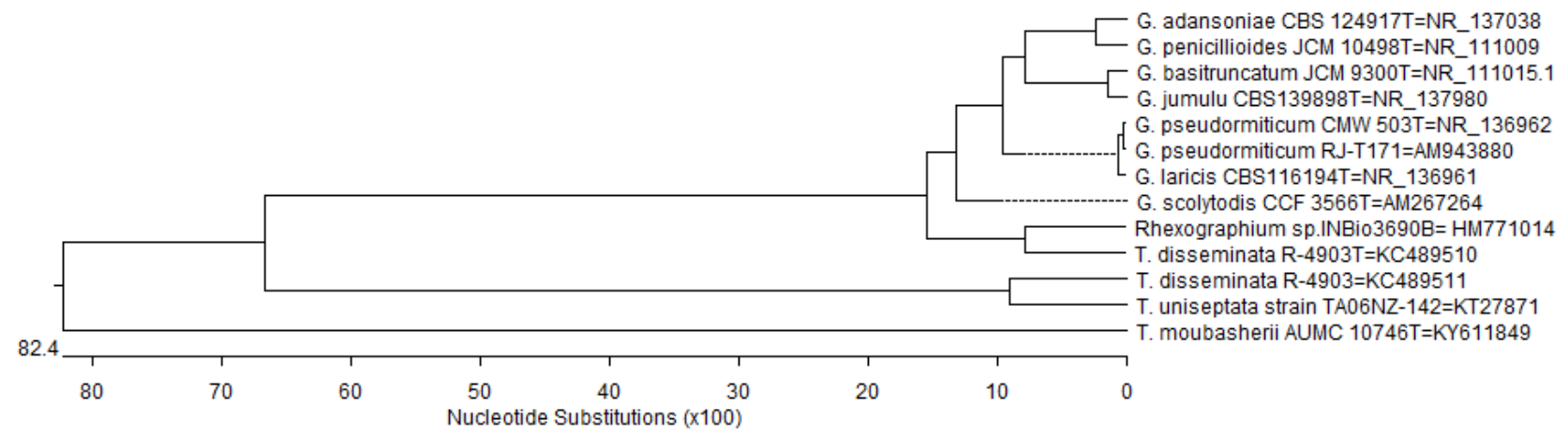

Fig 3 The phylogenetic tree of Triadelphia moubasherii based on partial nucleotide sequences (bp) of the ribosomal DNA internal transcribed spacer regions. The scale indicates the number of nucleotide substitutions per site. 
Table 1 Assiut University Mycological Center (AUMC no.) of the Triadelphia moubasherii strain isolated from red palm weevil together with GenBank accession numbers given together with the closest match in the GenBank database and sequence similarity in percent to the match as inferred from Blastn searches of ITS sequences.

\begin{tabular}{|c|c|c|c|c|c|c|c|}
\hline \multirow[t]{2}{*}{ AUMC no. } & \multirow{2}{*}{$\begin{array}{l}\text { GenBank accession } \\
\text { no. }\end{array}$} & \multirow{2}{*}{$\begin{array}{l}\text { Length } \\
\text { (pb) }\end{array}$} & \multicolumn{2}{|c|}{ Closest Genbank match \# ITS } & \multirow{2}{*}{$\begin{array}{l}\text { Sequence } \\
\text { similarity (\%) }\end{array}$} & \multirow[t]{2}{*}{ Identification } & \multirow[t]{2}{*}{ Source } \\
\hline & & & Accession no. & Culture collection code & & & \\
\hline \multirow{10}{*}{10746} & & & KC489510 & $\mathrm{R}-4903^{\mathrm{T}}$ & $567 / 601(94 \%)$ & Triadelphia disseminata & A patient with acute myeloid leukemia \\
\hline & KY611849 & 600 & HM771014 & INBio3690B & $443 / 516(86 \%)$ & Rhexographium sp. & Guts of beetle larvae \\
\hline & & & AM943880 & RJ-T171 & $360 / 413(87 \%)$ & Graphium pseudormiticum & Tetropiuim sp. colonizing Piceaabies \\
\hline & Triadelphia & & NR_137980 & CBS $139898^{\mathrm{T}}$ & $358 / 413(87 \%)$ & Graphium jumulu & Adansonia gregorii (Malvaceae) \\
\hline & moubasherii sp. & & NR_136962 & CMW $503^{\mathrm{T}}$ & $290 / 319(91 \%)$ & Graphium pseudormiticum & Pine bark beetle \\
\hline & & & NR_136961 & CBS $116194^{\mathrm{T}}$ & $290 / 319(91 \%)$ & Graphium laricis & A larvae of Ips cembrae on Larixdecidua \\
\hline & & & NR_137038 & CBS $124917^{\mathrm{T}}$ & $290 / 320(91 \%)$ & Graphium adansoniae & African baobab tree (Adansonia digitata) \\
\hline & & & NR_111015 & JCM $9300^{\mathrm{T}}$ & $290 / 322(90 \%)$ & Graphium basitruncatum & Forest soil \\
\hline & & & AM267264 & CCF $3566^{\mathrm{T}}$ & $287 / 322(89 \%)$ & Graphium scolytodis & Ambrosia beetle Scolytodes unipunctatus \\
\hline & & & NR_111009 & JCM $10498^{\mathrm{T}}$ & $289 / 325(89 \%)$ & Graphium penicillioides & Wood core of Populus nigra \\
\hline
\end{tabular}

Table 2 Synoptic table of different conidial forms (a-f) of different Triadelphia species recorded up-to-date.

\begin{tabular}{|c|c|c|c|}
\hline Species & Conidial forms & Type* & Reference \\
\hline T. uniseptata, T. australiensis\&T. centroseptata & 1 & a (1-septate) & Kirk 1983, Sutton 1989, Venkateshwarlu et. al. 1996 \\
\hline T. alabamensis & 2 & $\mathrm{~d}$ (multiseptate) \& e (1-3 septate) & Constantinescu \& Samson 1982 \\
\hline T. pulvinata, T. disseminata \& T. moubasherii & 3 & $\begin{array}{l}\text { a (1-septate), c (multiseptate) \& } \\
\text { e (0-septate) }\end{array}$ & $\begin{array}{l}\text { Maggi et al. 1978, Constantinescu \& Samson 1982, } \\
\text { Madrid et al. 2015, the present work }\end{array}$ \\
\hline T. morgoensis & 3 & $\begin{array}{l}\text { a (2-septate), c (multiseptate) \& } \\
\text { e (0-septate) }\end{array}$ & Revay 1992 \\
\hline T. loudetiae & 3 & $\begin{array}{l}\text { a (2-septate), c (multiseptate) \& } \\
\text { e (1-septate) }\end{array}$ & Maggi et al.1978, Constantinescu \& Samson 1982 \\
\hline T. heterospora & 4 & $\begin{array}{l}\text { a (2-septate), d (multiseptate), } \\
\text { e (1-septate) \& f (0-septate) }\end{array}$ & Shearer \& Crane 1971, Constantinescu \& Samson 1982 \\
\hline T. romanica & 4 & $\begin{array}{l}\text { a (1-septate), b (1-septate), } \\
\text { c (multiseptate) \& e (0-septate) }\end{array}$ & Constantinescu \& Samson 1982 \\
\hline Tdiversa & 5 & $\begin{array}{l}\text { a (1-2 septate), b (1-septate), } \\
\text { d (multiseptate), e (1-septate) \& } \\
\text { f (0-septate) }\end{array}$ & Tzean \& Chen 1989 \\
\hline T inquinans & 5 & $\begin{array}{l}\text { a (2-septate), b (1-septate), } \\
\text { c (multiseptate), e (1-septate) \& } \\
\text { f ( } 0 \text {-septate) }\end{array}$ & Hughes \& Pirozynski 1972, Constantinescu \& Samson 1982 \\
\hline T. hungarica & at least 2 & a (not recorded), d (multiseptate),no more available data & Revay 1987 (not available) \\
\hline T. queenslandica & at least 2 & a (not recorded), d (multiseptate), no more available data & Matsushima 1989 (not available) \\
\hline
\end{tabular}

ellipsoidal, pale brown, 0-septate (After Constantinescu \& Samson 1982). 


\section{Acknowledgements}

The authors are deeply indebted for Assiut University Mycological Centre for the financial support provided.

\section{References}

Abdel-Sater MA, Moubasher AH, Zeinab Soliman 2016 - Identification of three yeast species using the conventional and internal transcribed spacer region sequencing methods as first or second global record from human superficial infections. Mycoses 59, 652-661.

AL-Hedaithy SSA 2001 - First report of human infection due to the fungus Triadelphia pulvinata. Journal of Clinical Microbiology 39(8), 3386-3389.

Al-Hedaithy SSA, Leathers CR 1987 - Presence of Triadelphia pulvinata in Saudi Arabia and its potential pathogenicity. Proceedings of the Saudi Biological Society 10, 209-216.

Constantinescu O, Samson RA 1982 - Triadelphia, a pleomorphic genus of Hyphomycetes. Mycotaxon 15, 472-486.

Edathodu J, Al-Abdely HM, AlThawadi S, Wickes BL et al. 2013 - Invasive fungal infection due to Triadelphia pulvinata in a patient with acute myeloid leukemia. Journal of Clinical Microbiology 51(10), 3426-3429.

Hughes SJ, Pirozynski KA 1972 - Dicoccum Corda. Canadian Journal of Botany 50, 2521-2534.

Kirk PM 1983 - New or interesting microfungi IX. Dematiaceous Hyphomycetes from Esher Common. Transactions of the British Mycological Society 80, 449-467.

Madrid H, Silva V, Edathodu J, Sutton D 2015 - Triadelphia disseminata Madrid \& J. Edathodu, sp. nov. Persoonia 34, 234-235.

Maggi O, Bartoli A, Rumbelli A 1978 - Two new species of Triadelphia from rhizosphere of Loudetia simplex in the Ivory Coast. Transactions of the British Mycological Society 71, 148154.

Maharachchikumbura SSN, Hyde KD, Gareth EBG, McKenzie EHC et al. 2016 - Families of Sordariomycetes. Fungal Diversity 79, 1-317.

Matsushima T 1989 - Matsushima Mycological Memoirs No. 6. Matsushima Fungus Coll., Kobe, $100 \mathrm{pp}$.

Mercado SA, Castaneda RF 1983 - Nueva especie de Triadelphia (Hyphomycetes, Deuteromycotina) de Cuba. Revista del Jardín Botánico Nacional 4, 65-79.

Moubasher AH, Zeinab Soliman 2011 - Aspergillus assiutensis, a new species from the air of grapevine plantations, Egypt. Journal of Basic \& Applied Mycology, Egypt 2, 83-90.

Moubasher AH, Abdel-Sater MA, Zeinab Soliman 2017 - Yeasts and filamentous fungi inhabiting guts of three insect species in Assiut, Egypt. Mycosphere (In Press).

Patil VR, Borse BD 2015 - Aquatic fungi from Buldhana district (M.S., India) - III: Genus Triadelphia. International Journal of Science and Research (IJSR) 4(6), 2331-2353.

Ranghoo VM, Hyde KD 1998 - Ascolacicola aquatica gen. et sp. nov. and a new species of Ascotaiwania from wood submerged in a reservoir in Hong Kong. Mycologia 90, 1055-1062.

Ranghoo VM, Hyde KD, Liew ECY, Spatafora, IW 1999 - Family placement of Ascotaiwania and Ascolacicola based on DNA sequences from the large subunit rRNA gene. Fungal Diversity 2, 159-168.

Réblová M, Seifert KA,Fournier J, Štěpánek V 2016 - Newly recognised lineages of perithecial ascomycetes: the new orders Conioscyphales and Pleurotheciales. Persoonia 37, 57-81.

Révay Á 1987 - New or interesting Hyphomycetes on forest litter from Hungary. Acta Botanica Hungarica 33, 67-73.

Revay A 1992 - A new species of Triadelphia from Hungary. Studia Boanica Hungarica XXXIII, 63-68.

Samson RA, Hoekstra ES, Frisvad JC 2004 - Introduction to food- and airborne fungi. Centraalbureau voor Schimmelcultures - Utrecht, The Netherlands, pp. 378 - 382. 
Shearer CA, Crane JL 1971 - Fungi of the Chesapeake Bay and its tributaries. I. Patuxent River. Mycologia 63, 237-260.

Suh, S-O, Blackwell M 2004 - Three new beetle-associated yeasts in the Pichia guilliermondii clade. FEMS Yeast Research 5, 87-95.

Sutton BC 1989 - Notes on Deuteromycetes II. Sydowia 41, 330-343.

Thompson JD, Higgins DG, Gibson TJ 1994 - CLUSTAL W: improving the sensitivity of progressive multiple sequence alignment through sequence weighting, position-specific gap penalties and weight matrix choice. Nucleic Acids Research 22, 4673-4680.

Tzean SS, Chen JL 1989 - A new species of Triadelphia from Taiwan. Mycologia 81, 626-631.

Venkateshwarlu N, Reddy SM, Reddy SR 1996 - Hyphomycetes from Warangal - III. Indian Phytopathology 49, 339-341.

Wickerham LJ 1951 - Taxonomy of yeasts. Technical Bulletin 1029, US Deparment of Agriculture, Washington D.C. 